Digital Press Social Sciences and Humanities

\title{
Adult Self-Concept
}

Wirdatul 'Aini

Proceeding of The Non-Formal Education International Conference 2020

Alim Harun Pamungkas, Jamaris, Solfema (eds) 


\title{
Adult Self-Concept
}

\author{
Wirdatul 'Aini \\ Department of Non-Formal Education Universitas Negeri Padang, Padang, Indonesia \\ e-mail: wirdatulaini@fip.unp.ac.id
}

\begin{abstract}
Adult education is one form of education which is implemented at outside of formal schooling. The targets of adult education implemented at outside of school which is an adult who has experience to attend formal education. The experienced from adult has related to the implementation of education that included an adult who has not received formal education, dropped out from formal school or for those who has never completed formal education, but the adult wants to increase their knowledge, skills and attitude that adult needs in his daily life. Adult education that implemented outside school should be based on learning needs that grow from within themselves, and not based on the influence of conditions from outside themselves. For the success of an adult learning activity, out-of-school education practitioners need to pay attention to the factors that affect adults in learning and should understand the assumptions about adults in learning. Among the assumptions of adult in learning is that adult has selfconcepts. Adult self-concept among others has seemed themselves as independent people who are not dependent on others anymore. This self-concept as a guide for education practitioners to carry out learning activities for adults.
\end{abstract}

\section{Keywords}

self-concept, adult, learning activities

\section{Introduction}

Adult education is an education intended for an adult who is no longer as a child. An adult is a person who is already on puberty stage, if viewed in terms of age it is already 21 years old, or not yet 21 years old but already married. In terms of psychology, an adult is a person who has matured in terms of achievement, knowledge, skills, and attitudes of a person personally and can be utilized in social life. In adult education, the change in behavior of adult is the priority for adult to be able to stand alone. In teaching an adult outside of school is different from teaching a child in formal education. A child in formal education learns based on a curriculum that has been designed by an authority agency, which is designed by the Ministry of Education and Culture. Adult learning is based on learning needs that are felt by adult; therefore, the first step before teaching adult is to recognize adult learning needs.

In teaching adult, the adult educator should pay attention to aspects that underlie adult learning activities. There are several assumptions about adult in learning activities, namely: adults have a selfconcept (self-concept). When the individual has reached the stage of maturity, then the sense of dependence on another individual is decreased too. An adult can make decisions about themselves, and this is what is meant by the concept of self-concept. Self-concept means that an adult has a tendency to see themselves as a personality who has the full ability to determine the aim and purpose of their life. An adult also has their own sense of responsibility in determining and directing themselves. That is the meaning of adult self-concept. In order to make successful learning activities, there are implications of adult self-concept in learning, such as: (1) learning activities in adults need to create a pleasant climate/atmosphere, the need for spatial planning that creates comfort in learning, learning citizens can express their ideas freely in learning activities, (2) learning activities begin with the identification of needs, it will foster the learning motivation towards learning activities, (3) Then, the learning citizens are included in learning planning process, and the facilitator has a role as resource persons, mentors, (4) learning is a responsibility between learning citizens and the facilitators have more functions to motivate learning citizens to learn, and (5) there is an evaluation of learning activities in the form of self- 
evaluation, it means that learning citizens can assess themselves to what extent they can use / use will be things that are learned in everyday life.

The fact shows that a human cannot live alone without being dependent on others. The new human has a meaning, if they live side by side with other humans, and this is what human nature. The existence of communication illustrates that humans cannot live alone. The existence of trade illustrates that economic demands force humans to cooperate with others. The existence of schools requires a reciprocal relationship between student teachers and their social environment. There are still many other facts that show a human cannot live alone without the help of others human.

The definition of "self-concept" can be concluding as self-confidence, full responsibility that a person has, a sense of understanding of his environment. This term is used to describe the generation of a positive human conception of itself in relation to the environment and society. For example, a junior high school student after school, looking for activities with the aim of paying his school fee. We can say this student already has a self-concept when a student receives a shipment from his parents every month Rp. 500,000 with the knowledge just from notes by the lecturer. Adult as the learning citizens have a "selfconcept". The problem now is how a mentor or tutor, facilitator faces the adult who already have these self-concepts in the learning process. Because adults are not the same as small children, it is the necessary to use certain methods in teaching adults to facilitate their learning. Adults are not taught, adults are motivated, guided, and given facilities in order to find the latest knowledge, new skills and new attitudes and reach a better and perfect level of life.

Adult learning outcomes will be achieved well and satisfactorily if the mentor/facilitator use learning centered approach. Obviously in teaching adults an adviser must pay attention to citizens learning as individuals who are different from other individuals. In teaching adults according to Srinivasan (1979) we use the principles of self-determination and self-direction. Based on the approach as above, the responsibility of the tutor/facilitator is to encourage and guide the ability of citizens to learn to direct and develop themselves as far as possible. The attitude of the teacher, mentor, and facilitator must be based on the belief that if a situation is created that is right and good then the citizens of learning can develop themselves, have skills, work and work actively. Then learning in adults is intended to realize itself (selfactualizing). For adults a better and possible way of learning is to see themselves and the environment, so they can grow and develop as individual creatures and as social beings. To achieve a better level of life clearly requires learning process and requires knowledge.

The appropriate way to be used in adult learning activities is a way that is in accordance with the selfconcept that has been owned. Adult learning citizens cannot be compared to school of children in learning. In formal schools the curricula have been determined which is designed in advance, the hours of study are clear, where learning is available in a particular room. On the other hand, it is different with what adult learn which is determined for them what they will learn, even what goals adults want to achieve. According to Abdulhak (1996), and Tamat (1985) the formulation of adult learning goals is carried out by learning citizens together so that the goals are truly in line with their expectations. A mentor, tutor, facilitator only helps facilitate their learning. Counselors only provide facilities; motivate them in learning, so that students realize that education is a process of improving and developing selfability. It is expected that the potential that exists in him can develop as much as possible. The knowledge they have gained today can achieve a better or more effective life for the day to come. Thus, the learning process must be arranged in such a way so that it can develop its abilities.

\section{Discussion}

In introduction it has been explained that the assumptions about adult can be stated according to Arif (1984) first adult have self-concept, it means that adult in their lives are no longer dependent on others, can already be responsible for themselves and also be responsible for their environment more broadly, such as being responsible for his children, his parents, as well as being responsible for activities carried out at work, in the community, etc. Adult self-concept has been explained thoroughly in the introduction. However, when compared to children, they have low self-concept. Children are more dependent on adults or others. Children are a personality who cannot be independent, cannot be responsible for their activities. It can be argued that almost the whole life and life of children is still determined and regulated by their parents, other adults who are in the school, family or community. Furthermore, when children begin to reach maturity, personality dependence on others begins to decrease. Gradually humans who have begun to grow up can become individuals who are able to stand alone, able to regulate themselves. 
Therefore, in every activity, learning, or training adult need to be treated by others to be appreciated in terms of making a decision.

Adults certainly don't want to be treated the same as children as taught everything related to this can be done and it should not be done. Then adults will not accept if in a learning situation contrary to something that is expected, and the situation is contrary to the concept of himself as an individual who can stand on the ability and strength of his own. Furthermore, it can be stated that if adults are in the learning process they can be treated with mutual respect for every difference, mutual respect for each other, it is certain that adults will be able to participate in learning activities more intensively. The implications in adult learning activities are: (1) the learning atmosphere needs to be created in accordance with the conditions of adults, such as learning facilities chairs, tables etc. can be arranged in accordance with learning citizens, (2) adult learning participants must participate or be involved in determine their learning needs, (3) thus they will also be involved in planning learning activities, (4) the role of the facilitator, the instructor guides more, directs and motivates adults in learning, and (5) evaluates adult learning more emphasis on self-evaluation means the extent to which an adult is able to judge himself about the material provided can provide benefits and useful in adult life.

The second assumption regarding adults is experience. The intended experience is that adults have lived for a long time; of course, they also have lots of ups and downs in their live. There are many good and bad experiences that have made him more able to use his experience as strength to deal with problems in his life. If observed between the experiences of children and adults are certainly different. The difference can be seen that the experience that occurs in children is something that comes from outside himself, while the experience of an adult is something that he experiences comes from himself and influences, and an integral part of his life. With the difference in experience between adults and children, of course in learning activities will also be different in terms of the utilization of learning outcomes. If adults learn they want what is learned to have a contribution in their lives, or there are benefits in their lives. Adults are rich with experience, so that the experience they have will be able to support the learning activities undertaken. Adult experience will be the basis for developing activities for the future

Then it can be stated the implications of adult experience in learning, among others: 1) adults are the main source in their learning activities, the learning techniques used in learning activities can foster more adult motivation in learning, such as discussion techniques, simulations, role playing, practical activities, training, etc., 2) learning activities prioritize applications, and can be practically used in adult life, 3) learning from experience becomes the priority aspect in learning activities. The learning process based on experience will enable adults to realize themselves (self-direction).

Then the third assumption, which is readiness to learn. It can be argued that adults will be ready to learn based on the period of development they go through. Adults will be interested in learning, of course, which can be in line and support their developmental tasks. For example, young adults will be ready to learn in connection with or support their developmental tasks as young adults whose being ready to learn to care for, educate children at an early age, because in early adulthood they are generally just beginning to live family / married, of course people Today is only the first to start educating children under five. Then in the work of adults today are ready to improve their careers, to be more successful and better able to develop their abilities in the workplace as well as many more examples of adult readiness in learning in line with the developmental tasks they experienced theoretically. For this reason, it can be stated that the implications of adult learning activities include: 1) planning of adult learning programs based on their developmental tasks, and not based on specific subjects that have been addressed by the institution, and 2) the existence of development tasks will be a guide in group learning, based on homogeneity will be more effective

The fourth assumption is orientation towards learning. The orientation or direction / learning goals of adults and children are different. Learning activities in children are oriented to the future or the results are practically not visible at the present time. Conversely, the orientation of learning in adults can immediately be applied to their daily lives. It can be argued that adults will be present in learning activities if what they learn is related to their needs, and they can immediately apply it immediately in their daily lives. Therefore it can be stated the implications of adult learning activities including: (1) adult educators do not act as a teacher who can teach a variety of subject subjects, but the teacher acts as a facilitator, as a guide who can help adults in learning, (2) learning programs are not directed based on subjects that are determined, but learning programs are based on problems faced by learning citizens, and (3) learning activities are designed based on the things that are the center of attention of adults. 


\section{Conclusion}

The concept of self (adult self-concept) can be interpreted that adults can already be seen as people who can be independent or not dependent on others. In everyday life adults can carry out activities responsibly and be able to determine and direct themselves to the goals they set themselves. Adult selfconcept is seen as an attitude of self-confidence, a positive conception of itself. The adult feels that he is a personality who is capable of being responsible for work and can support himself and of course is responsible for his family, children and other family members in his home.

Adults have a principle in their lives that it is better to live on their own than to ask for help from other family members for survival. For example, adults try to make ends meet based on the work that is just enough to meet their needs rather than asking for donations from relatives who have more material. An adult feels low self-esteem when asking material help from his own relatives. That is the meaning of selfconcept more broadly and more thoroughly.

Furthermore, the assumptions about adults are related to experience, and that is adults have plenty of experience, that will affect them in learning. Adults will be present in an activity if the adult experience in learning activities becomes a guideline in the development of learning activities. Adults will be present in an activity if learning activities can develop, helping adults to develop their experiences.

The next assumption is readiness to study. Adults will be ready to learn if the material taught by the instructor is related to the developmental tasks experienced in the adult period. Every human being psychologically based on the period of development there are tasks that must be able to be carried out in accordance with the period that is passed. For example, early adults among the development tasks that must be done is to educate children under five, because in theory in early adulthood humans will give birth, of course, have children under five. All activities related to the care of children under five will be studied by early adults.

Then the assumption about adults is orientation in learning. The orientation of adults with children is different in learning. Learning and learning outcomes obtained by children can be enjoyed in the future. But the orientation of adults in learning is that they expect things learned today to be useful in their present life and can be used to achieve a better life for the future.

\section{References}

Abdulhak, I. (1996). Metodologi Pembelajaran pada Pendidikan Orang Dewasa. Bandung: Cipta Intelektual.

Arif, Z. (1984). Andragogi. Bandung: Penerbit Angkasa.

Srinivasan, L. (1979). Beberapa Pandangan Mengenai pendidikan Nonformal bagi Orang Dewasa. Bandung: Balai Pengembangan Kegiatan Belajar (BPKB) Jayagiri.

Tamat, T. (1985). Dari Pedagogik ke Andragogik. Jakarta: Pustaka Dian. 